Vol. 4, No. 4, 2019

\title{
SCIENTIFIC PRIORITIES OF THE DEVELOPMENT OF ENVIRONMENTAL RESEARCH IN ODESSA NATIONAL ACADEMY OF FOOD TECHNOLOGIES. THE LIFE PATH OF PROFESSOR KRUSIR G.V.
}

\author{
Olga Sagdeeva \\ Odessa National Academy of Food Technologies, \\ 112, Kanatna Str.,Odessa, 65039, Odessa, Ukraine \\ sagolanis@ukr.net
}

https://doi.org/10.23939/ep2019.04.219

Received: 30.10 .2019

(C) Sagdeeva O., 2019

\begin{abstract}
The article deals with the main scientific priorities of the development of environmental research in Odessa National Academy of Food Technologies under the leadership of the Head of the Department of Ecology and Environmental Technologies, Doctor of Technical Sciences, Professor Krusir G. V. Current priorities of her scientific research are the enzymatic catalysis, digestive (hydrolytic) enzymes, immobilization of biologically active substances, biocorrectors of digestive processes, biotechnology, ecobiotechnology, resource efficiency in the food chain, ecological management, biotechnological methods of recycling of the secondary raw materials of food industry into biologically active additives, determination of environmental friendliness of foodstuffs by chemical methods and non-destructive methods, processes of anaerobic fermentation of waste with the formation of biogas, sewage treatment of food production by the method of anaerobic digestion, technology of processing food industry waste into biologically active feed additives and organic fertilizers.
\end{abstract}

Key words: ecological safety, biotechnology, biotechnological methods of recycling, anaerobic fermentation, sewage treatment.

Krusir Galyna Vsevolodivna is Doctor of Technical Sciences (2009), Professor (2013), chemist, environmental engineer, biotechnologist. She was born on 1 May 1965 in the Odessa region. Galyna Krusir graduated from the Faculty of Chemistry of Odessa I. I. Mechnikov State University in 1987 specializing in organic chemistry.

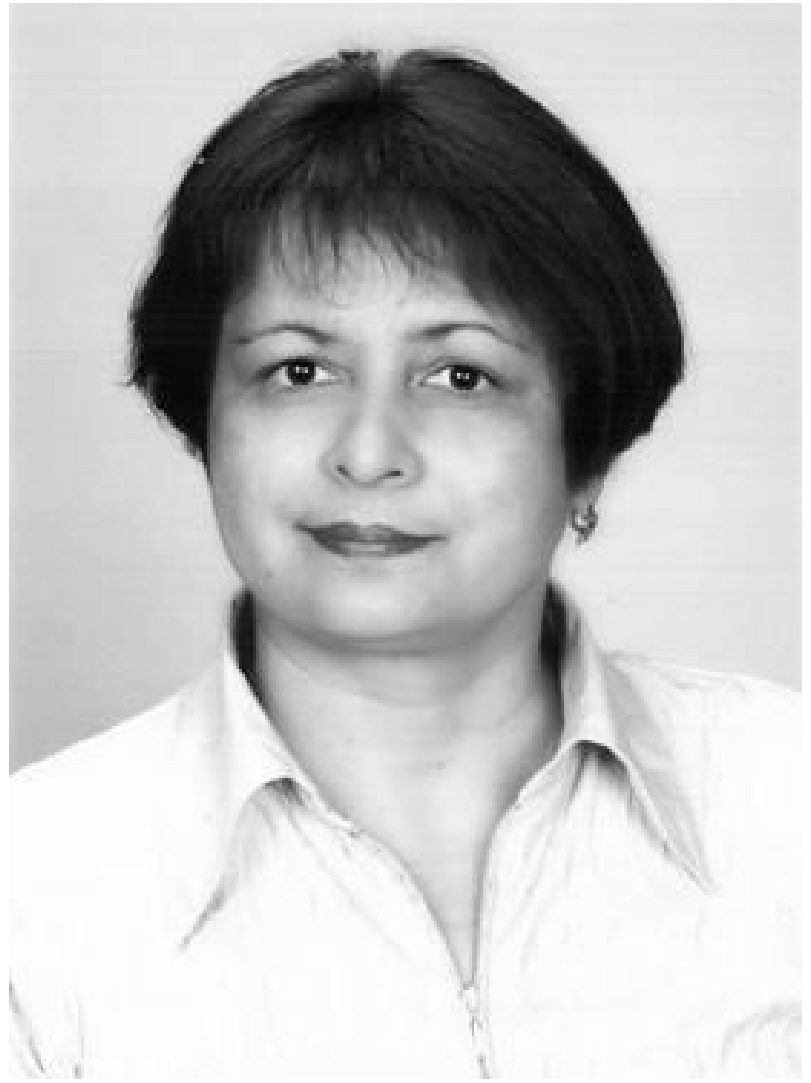

After graduating from the Odessa State University, she worked as an engineer and junior researcher at the Problem Research Laboratory of Complex Processing of Vegetable Raw Materials into Foodstuffs of the Odessa M. V. Lomonosov Technological Institute of Food Industry, and after defending her $\mathrm{PhD}$ thesis (1993) in the specialty 03.00.20 - Biotechnology (Technical Sciences) 
she became an assistant and associate professor of the Organic Chemistry Department of the same institution of higher education in the period from 1994 to 2010.

Between November 1995 and November 1996, Galyna Krusir received the European higher education in engineering ecology at the University of Applied Sciences of Northwestern Switzerland in Basel, Switzerland.

Doctoral dissertation on the topic "Scientific Bases of Biotechnology of Food Digestion Process Correctors", specialty 03.00.20. - Biotechnology (162 Biotechnology and Bioengineering) was defended at the Odessa National Academy of Food Technologies in 2009.

Since 2010 Krusir G. V. has been the Head of the Department of Ecology and Environmental Technologies of the Odessa National Academy of Food Technologies.

From 2013 to 2014 Krusir G. V. was the Member of the Ukraine State Accreditation Commission, since 2011 she has been the scientific secretary of the specialized scientific council D 41.088.02 in defense of the dissertations for the Doctor (Candidate) of Technical Sciences degree in specialty 03.00.20 - Biotechnology (Technical Science), 05.18.04 - Technology of Meat, Dairy and Hydrobiont Products (Technical Sciences), 05.18.16 - Food Technology (Technical Sciences).

From 2012 to 2015 Krusir G. V. was the coordinator of the United Nations Industrial Development Organization (UNIDO) project "Promoting the adaptation and implementation of resource efficient and cleaner production through the creation and operation of a Center of Resource Efficient and Cleaner Production in Ukraine". She is a UNIDO expert on resource efficient and cleaner production.

Krusir G. V. is a member of editorial boards of 3 scientific journals "Food Sciences and Technologies", "Environmental Problems", "Technogenic and Ecological Safety".

In addition to scientific and teaching activities Galyna Krusir also performs community service. She chairs the ONAFT Methodological Council on specialties 101 "Ecology" of the Knowledge Branch 10 "Natural Sciences" and 183 "Environmental Technologies" of the Knowledge Branch 18 "Manufacturing and Technology", as well as a commission on diploma design and practical training of the ONAFT Methodological Council. She has repeatedly been a member and head of the MESU accreditation and licensing commission, an opponent at thesis defending.

From 2016 to 2019 Krusir G. V. was a member of the Scientific and Methodological Commission on Higher Education of the Ministry of Education and Science of Ukraine, specializing in 183 Environmental Technologies, a developer of higher education standards of Ukraine for the degrees of Bachelor, Master and Doctor of Philosophy.

Krusir G. V. is the scientific adviser of three $\mathrm{PhD}$ theses - one in specialty 03.00.20 - Biotechnology
(Technical Sciences) (2010) and two in specialty 21.06.01 - Ecological Safety (Technical Sciences) (2016 and 2019). She currently directs the work of 2 postgraduate students and heads the scientific school "Theory and Practice of Environmental Technologies", which focuses on the scientific substantiation and practical aspects of technologies implementation based on natural mechanisms of stabilization of ecosystems and environmental components.

More than 30 years Galyna Krusir has been engaged in teaching and research activities in the field of biochemistry of plant raw materials, biotechnology of foodstuffs and biologically active additives, biotechnological bases of processing secondary raw materials of food industry into biologically active and feed additives.

Areas of professional competence of Krusir G.V. are the enzymatic catalysis, digestive (hydrolytic) enzymes, immobilization of biologically active substances, biocorrectors of digestive processes, biotechnology, ecobiotechnology, resource efficiency in the food chain, ecological management, methodology of cleaner production, ecological labeling, life cycle assessment, identification of the best available technologies in the industry, biotechnological methods of recycling the raw materials of food industry into biologically active additives, determination of environmental friendliness of foodstuffs by chemical methods and non-destructive methods (biotesting, biocrystallization, etc.); processes of anaerobic fermentation of waste with the formation of biogas, sewage treatment of food production by the method of anaerobic digestion, composting the food component of municipal waste, technology of processing food industry waste into biologically active feed additives and organic fertilizers.

Under the current license terms, Krusir G. V. has 15 results and achievements over the last 5 years.

Her teaching is related to the preparation of bachelors and masters in specialties 101 "Ecology" and 183 "Environmental Technologies". Among the disciplines that have been taught by Galyna Krusir are the following: "Environmental Management and Audit", "Environmental Protection Management", "Environmental Chemistry", "Environmental Control", "Waste Management Technologies".

Krusir G. V. was awarded with the certificates of the mayor and the Minister of Ecology and Natural Resources of Ukraine, the Order of the Council of Rectors of Higher Education Institutions of the Odessa region "For contribution to the development of higher education", the certificates of the ONAFT administration.

She has published more than 380 scientific works, including 5 monographs [1-5] and 10 textbooks and manuals with the stamp of the Ministry of Education and Science [6-15], 8 patents [16-23]. Nowadays, 5 publications by Krusir G.V. are indexed in Scopus and WoS [24-28]. 


\section{References}

[1] Cherno N. K. Digestors of digestive processes [Text] / N. K. Cherno, G. V. Krusir, O. V. Kovalenko / Monograph. Odessa. 2010. 236 p.

[2] Krusir G. V. Sustainable development and security of Ukraine's agro-food sector in the face of globalization challenges / G. V. Krusir, O. I. Pavkov, M. A. Hvesik, V. V. Yurchishin // Astroprint Odessa, 2012. P. 440-452.

[3] Krusir G. V. Ecology in diagrams and tables / G. V. Krusir, E. P. Ruseva, G. V. Kiriyak, O. S. Karpenko, V. V. Yashkina, I. F. Sokolova, R. I. Shevchenko // Odessa, ONAFT, Department of Food and Production Ecology, 2013. 162 p.

[4] Galyna Krusir, Heinz Leuenberger, Olesia Cernyshova Investigation of Co-Utilization of Meat Processing Wastewater Sewage and Rice Husk by Anaerobic Digestion. - P. 66-76. / in Monograph "Water Security", edited by Olena Mitryasova \& Chad Staddon. Mykolaiv: PMBSNU - Bristol: UWE, 2016. 308 p.

[5] Galyna Krusir, Alfred Zikalo, Oleksiy Harkovych, Maria Madani, Valentina Zakharchuk Anaerobic Treatment of Wastewater from Wineries. P. 76-88. / in Monograph "Water Security", edited by Olena Mitryasova \& Chad Staddon. Mykolaiv: PMBSNU Bristol: UWE, 2016. $308 \mathrm{p}$.

[6] Waste management technologies: Educ. tool for HEI students. / G. V. Krusir, R. I. Shevchenko, Ya. P. Ruseva, I. P. Kondratenko, I. P. Krajnov. Odessa, 2014. 304 p.

[7] Krusir G. V., Madani M. M., Garkovich O. L. Techniques and technologies of gas emission purification. Manual. Odessa, 2018. $157 \mathrm{p}$.

[8] Krusir G. V., Madani M. M., Garkovich O. L. Ecological Chemistry Handbook. Odessa, 2018. 187 p.

[9] Krusir G. V., Madani M. M., Garkovich O. L., Chernyshova O. O. Environmental Law Guide. Odessa, 2018. 165 p.

[10] Krusir G. V., Trishin F. A., Madani M. M., Garkovich O. L. Technoecology Guide. Odessa, 2018. 178 p.

[11] Krusir G. V., Madani M. M., Karpenko O. S. Theoretical Foundations of Environmental Protection Guide. Odessa, 2018. 197 p.

[12] Petruk V. G., Vasylkivsky I. V., Petruk R. V., Krusir G. V., Klimenko M. O., Sakalova G. V. Environmental protection technologies. Textbook. Part 1: Protecting the Vinnitsa atmosphere: VNTU, 2019. 327 p.

[13] Petruk V. G., Vasilkovsky I. V., Petruk R. V., Krusir G. V., Klimenko M. O., Sakalova G. V. Environmental protection technologies. Textbook. Part 2: Protection of the Vinnitsa hydrosphere: VNTU, 2019. 363 p.

[14] Petruk V. G., Vasilkovsky I. V., Petruk R. V., Krusir G. V., Klimenko M. O., Sakalova G. V. Environmental protection technologies. Textbook. Part 3: Environmental Protection Management, Vinnitsa: VNTU, 2019. 250 p.

[15] Petruk V. G., Vasilkovsky I. V., Petruk R. V., Krusir G. V., Klimenko M. O., Sakalova G. V. Environmental protection technologies. Textbook. Part 4: Technologies of food waste management, Vinnitsa: VNTU, 2019. 340 p.

[16] Pat. for invention No. 91080 Ukraine. A23L 1/30, A23L 1/10 Biologically active additive / Krusir G. V., Kushnir N. A.; Owner: Odessa National Academy of Food Technologies. - u200805352; Statement 04/24/2008; publ. 25.06.2010 Bul. No. 12/2010.
[17] Pat. for invention No. 46784 Ukraine. A23L 1/30, A23L $1 / 10$ Method for the production of a curative preventive fermented milk beverage / Krusir G. V., Kushnir N. A.; Owner: Odessa National Academy of Food Technologies. u200906055; Statement 06/12/2009; publ. 11.01.2010. Bul. No. 1/2010.

[18] Pat. for invention No. 48539 Ukraine. A23L 1/308, A23L 1/30 Biologically active additive / Krusir G. V., Kushnir N. A.; Owner: Odessa National Academy of Food Technologies. u200909257; Statement 08/09/2009; publ. 25.03.2010. Bul. No. 6/2010.

[19] Pat. for utility model No.87896 Ukraine. G01N 33/18 Food safety assessment method / G. V. Krusir, I. P. Kondratenko; Owner: Odessa National Academy of Food Technologies. - u201310181; Statement 19.08.2013; publ. 02/22/2014 Bul. No. 4.

[20] Pat. For utility model No. 94587 Ukraine IPC (2014) C02F 11/12. Method of anaerobic digestion of sewage sludge / Krusir G. V., Sokolova I. F. Applicant and patentee of ONAFT. u201403878; Statement 14.04.2014; publ. 25/11/2014, Bul. No. 22. 4 p.

[21] Pat. Utility Model No. 83595 Ukraine IPC Method of obtaining feed additive / Krusir G. V., Sokolova I. F. Applicant and Patent Owner of ONAFT. u2012 14030; Statement 10/12/2012; publ. 9/25/2013, Bul. No.18. 6 p.

[22] Pat. for utility model No.128399 Ukraine. CO2F 7/00 Method of composting the organic part of solid household waste / G. V. Krusir, O. A. Sagdeeva, A. L. Tsykalo, I. V. Kovalenko, O. L. Garkovich; Owner: Odessa National Academy of Food Technologies. u201804987; Statement 07/05/2018; publ. 09/09/2018 Bul. No. 17.

[23] Pat. for the utility model No.128398 Ukraine. CO2F 7/00 Method of composting the organic part of solid [22] household waste / G. V. Krusir, O. A. Sagdeeva, A. L. Tsykalo, M. M. Madani, I. O. Kuznetsova; Owner: Odessa National Academy of Food Technologies. u201804983; Statement 07/05/2018; publ. 09/09/2018 Bul. No. 17.

[24] O. A. Sagdeeva, G. V. Krusir, A. L.Tsykalo, T. V. Shpуrко, H. Leuenberger. Organic waste composting using mineral additives // Food Science and Technology. 2018. Vol. 12 (1). P. 45-52. DOI: http://dx.doi.org/10.15673/fst.v12i1.842 (WoS)

[25] Malovanyy M., Krusir G., Holodovska O., Masikevych A. Reagent purification of the processing industry enterprises effluents // Food Science and Technology. 2018. Vol. 12 (3). P. 109-116. DOI: https://doi.org/ 10.15673/fst.v12i3.1046 (WoS)

[26] Skliar V., Krusir G., Zakharchuk V., Kovalenko I., Shpyrko T. Investigation of the fat fraction enzymatic hydrolysis of the waste from production of hydrogenated fat by the lipase Rhizopus japonicus // Food science and technology. 2019. Vol. 13 (1). P. 27-33. DOI: http://dx.doi.org/10.15673/fst.v13i1.1332 (WoS)

[27] Victoria Sklyar, Galina Krusir, Tatyana Lebedenko, Galina Khomich, Irina Kovalenko. Research Study of the Conditions of Wastes Lipolysis Lipid Fraction // Journal of Ecological Engineering. 2019. Vol. 20 (3). P. 152-156 https://doi.org/10.12911/22998993/99745 (Scopus)

[28] Krusir G., Shpyrko T., Sagdeeva O., Zakharchuk V. The role of soil microbiocenosis in the composting process of the organic part of municipal solid waste // Food Science and Technology. 2019. Vol. 13(2). P. 34-43. https://doi.org/10.15673/fst.v13i2.1387 